\title{
Correction to: Genomic Breeding of Green Super Rice Varieties and Their Deployment in Asia and Africa
}

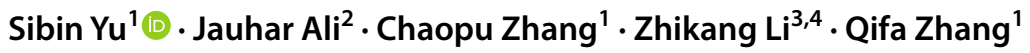

Published online: 19 February 2020

(c) The Author(s) 2020

\section{Correction to: Theoretical and Applied Genetics https://doi.org/10.1007/s00122-019-03516-9}

The article Genomic Breeding of Green Super Rice Varieties and Their Deployment in Asia and Africa, written by Sibin Yu, Jauhar Ali, Chaopu Zhang, Zhikang Li and Qifa Zhang, was originally published electronically on the publisher's internet portal on 8th January 20120 without open access. With the author(s)' decision to opt for Open Choice the copyright of the article changed on 28th January 2020 to $($ ) The Author(s) 2020 and the article is forthwith distributed under a Creative Commons Attribution 4.0 International License (https://creativecommons.org/licenses/by/4.0/), which permits use, sharing, adaptation, distribution and reproduction in any medium or format, as long as you give appropriate credit to the original author(s) and the source, provide a link to the Creative Commons licence, and indicate if changes were made.

The original article has been updated.

Open Access This article is licensed under a Creative Commons Attribution 4.0 International License, which permits use, sharing, adaptation, distribution and reproduction in any medium or format, as long as you give appropriate credit to the original author(s) and the source,

The original article can be found online at https://doi.org/10.1007/ s00122-019-03516-9.

Zhikang Li

zhkli1953@126.com

Qifa Zhang

qifazh@mail.hzau.edu.cn

1 National Key Laboratory of Crop Genetic Improvement, Huazhong Agricultural University, Wuhan 430070, China

2 International Rice Research Institute, DAPO Box 7777 Metro Manila, Philippines

3 Institute of Crop Sciences, Chinese Academy of Agricultural Sciences, Beijing, China

4 College of Agronomy, Anhui Agricultural University, Hefei, China provide a link to the Creative Commons licence, and indicate if changes were made. The images or other third party material in this article are included in the article's Creative Commons licence, unless indicated otherwise in a credit line to the material. If material is not included in the article's Creative Commons licence and your intended use is not permitted by statutory regulation or exceeds the permitted use, you will need to obtain permission directly from the copyright holder. To view a copy of this licence, visit http://creativecommons.org/licenses/by/4.0/.

Publisher's Note Springer Nature remains neutral with regard to jurisdictional claims in published maps and institutional affiliations. The original article has been updated. 